\title{
トルク法によるタービン発電機セグメントコアの鉄損評価
}

\begin{tabular}{|c|c|c|c|c|}
\hline 員 茂木 & 尚* & 正 & 中原 & 明仁** \\
\hline 員 高橋 & 和彦** & 上級会員 & 世 & 一正 ${ }^{* *}$ \\
\hline 員 & 力 ${ }^{*, *}$ & 非会員 & 金田 & 潤 \\
\hline & 憲一**** & 非 会 & & \\
\hline & 英資* & 非会 & & \\
\hline
\end{tabular}

\section{Core Loss Evaluation of Segment Core in Turbine Generators by Torque Method}

\author{
Hisashi Mogi*, Member, Akihito Nakahara**, Member, Kazuhiko Takahashi**, Member, \\ Kazumasa Ide**, Senior Member, Chikara Kaido*,***, Member, Junya Kaneda**, Non-member, \\ Ken'ichi Hattori****, Member, Takashi Watanabe $^{* * * *}$, Non-member, Eisuke Minematsu*5, Non-member, \\ Kazufumi Hanzawa*6, Non-member
}

This paper presents core loss evaluation of turbine generator model stator. The stator configuration does not make magnetic flux distribution uniform, and the induction harmonics make the core loss calculation difficult. In this evaluation, the core losses are measured by rotating stator torque.

As a result of the measurements, a half-lap-stacked stator obtains lower core losses and larger percentage of eddy current losses than a block-stacked stator. In addition, a gap between each segment makes in-plane eddy current loss increase.

キーワード : タービン発電機, セグメントコア, けい素鋼板, トルク法, 面内渦電流

Keywords: turbine generator, segment core, silicon steel, torque method, in-plane eddy current

\section{1. はじめに}

高効率，高信頼性が求められているタービン発電機の固

$*$ 新日本製鐵（株） 技術開発本部 鉄鋼研究所

干 293-8511 富津市新富 20-1

Steel research laboratories, Nippon Steel Corp.

20-1, Shintomi, Futtsu 293-8511

**（株）日立製作所研究開発本部 日立研究所

厂 319-1292 日立市大みか町 7-1-1

Hitachi research laboratory, Hitachi, Ltd.

7-1-1, Omika, Hitachi 319-1292

*** 九州工業大学大学院工学研究科

于 884-8550 北九州市戸畑区仙水町 1-1

Graduate school of engineering, Kyushu Inst. of Technology

1-1, Sensui, Tobata-ku, Kitakyushu 884-8550

****（株）日立製作所電力グループ，日立事業所

テ317-8511 日立市幸町 3-1-1

Hitachi Works, Power Systems, Hitachi, Ltd.

3-1-1, Saiwai, Hitachi 317-8511

$* 5$ 新日本製鐵（株）名古屋支店 薄板グループ

于 476-8686 東海市東海町 5-3

Nagoya branch, Nippon Steel Corp.

5-3, Tokaicho, Tokai 476-8686

*6 新日本製鐵（株）八幡製鐵所

厂 804-8501 北九州市戸畑区飛幡町 1-1

Yawata Works, Nippon Steel Corp.

1-1, Tobihatacho, Tobata-ku, Kitakyusyu 804-8501
定子には様々な高度技術が適用され(1) (4), 特に固定子は詳 細な磁束密度分布, 渦電流分布が解析されている ${ }^{(5)(6)}$ 。

タービン発電機の損失のうち, 鉄損は特に推定が難しい。 これは鉄損がけい素鋼板の磁気特性に依存するからである。 タービン発電機の固定子はけい素鋼板が積層した分割ブロッ ク（セグメント）として構成されている。分割された固定 子中の磁束流れは, その形状や材料の磁気異方性から影響 を受け, 不均一である。したがって, 均一磁束分布で測定 したけい素鋼板のカタログ揭載データをそのまま用いると 実機駆動における固定子鉄損の推定に誤差を生じる。さら に励磁周波数によっても材料の磁気特性に応じて固定子鉄 損は変化し, また, 固定子鉄心の積層方式の違いによる鉄 損増分の変化等, これらを分離して測定することは難しく, 推定精度の向上を妨げている。

これら鉄損の増加因子を考慮した推定方法を検討するた め, 従来開示されているギャップの影響や面内渦電流分布 の解析を元に, 本研究においては実測によって, ヒステリ シス損失, 渦電流損失を分離し, タービン発電機の数值解 析用ギャップモデルと渦電流損失を比較した。ここでいう 実測した鉄損とは，積層方法やセグメント間のギャップの 影響も評価可能なトルク法より求めたものである。鉄損の 評価には外乱である鋼板への圧縮応力や層間短絡を可能な 
限り除き, 固定子形状, 材料磁気特性のみを評価できる回 転鉄損シミュレータ(7)を用いた。

\section{2. 実験方法}

実験における固定子は，図 1 に示すセグメント 15 個で 構成した。セグメントの寸法を図 2 に示す。1 つのセグメ ントは 2 本の歯を持つ。これは通常の大容量タービン発電 機の約 $1 / 20$ のモデルに相当する。

材料は無方向性けい素鋼板 50H350, 板厚 $0.5 \mathrm{mm（JIS}$ 50A350）を用いた。セグメントの剪断は歪の影響が少ない ワイヤーカットで行った。セグメントは図 3 に示すテフロ ンフレームにはめ込み, 積層数を 7 層にし, プラスチックの 押さえで固定した。このフレームを用いることで，セグメ ントを容易に交換できる。また，セグメント間の隙間は開か ないように設計されているが，セグメント間に生じるギャッ プの影響を見るため，セグメントの幅（最大 $27.0 \mathrm{~mm}$ ）を 両端から $0.4 \mathrm{~mm}$ ずつ（計 $0.8 \mathrm{~mm}$ ）短くし，ギャップを設 けた固定子も作製した。

固定子試料の鉄損は，図 4 に示す回転鉄損シミュレータ により測定した。これは一定速で回転する試料に回転磁界 を印加し，鉄損により発生する回転方向と逆のトルクを測定 することで鉄損が評価できる。トルク計は小野測器製 TS900A, 発信器とアンプは NF 回路設計ブロック製 FG-124, S-4750を用いた。

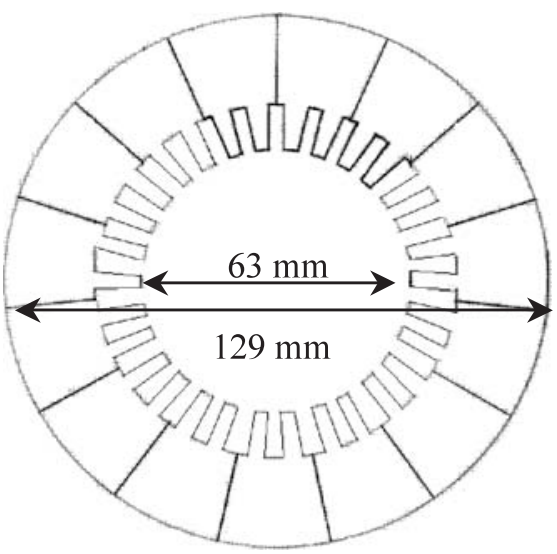

図 1 モデル固定子

Fig. 1. Model stator.

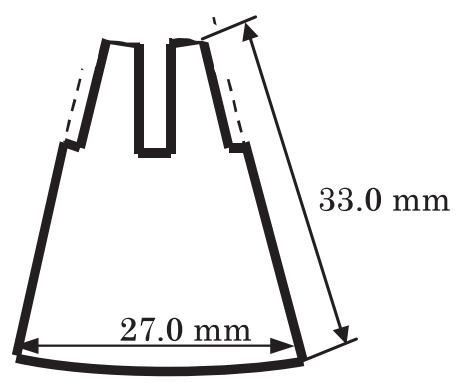

図 2 セグメント

Fig. 2. A piece of segment.
試料の中心には図 4 左側に示す励磁ヨークが入る。励磁 ヨークは $10.5 \mathrm{~mm}$ 幅の 12 個の歯からなり, XY 方向それ ぞれに巻線が施してある。本実験では回転磁界を発生する

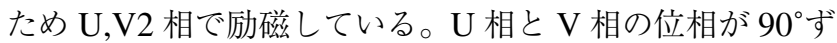
れた正弦波を加えることにより，回転磁界が発生する。

試料フレームは一定の回転数 $(300 \mathrm{rpm})$ で回り，回転磁 界の周波数で試料中の磁束周波数を設定することができる。 回転数 $300 \mathrm{rpm}$ は $5 \mathrm{~Hz}$ に相当し, 固定子試料そのものに $50 \mathrm{~Hz}$ で励磁するためには，機械的回転数を加えた $55 \mathrm{~Hz}$ で励磁ヨークから回転磁界を印加する必要があり, 注意を 要する。また，励磁ヨークから試料表面へ流れるフリンジ ング磁束の影響は，ヨーク部が $1.5 \mathrm{~T}$ の時，ティース先端 で $0.012 \mathrm{~T}$ と $0.8 \%$ の影響であり，かつ先端を離れると磁束 が急激に減少するので，全鉄損に与える影響は少ないと考 える。

試料を励磁すると鉄損が生じてエネルギーが消費される。 一方，回転数一定下でトルクが発生するため，外部から同 量の機械エネルギーが入力し，(1) 式により単位重量あたり の鉄損が得られる。

$$
W=\frac{2 \pi f T}{M}
$$

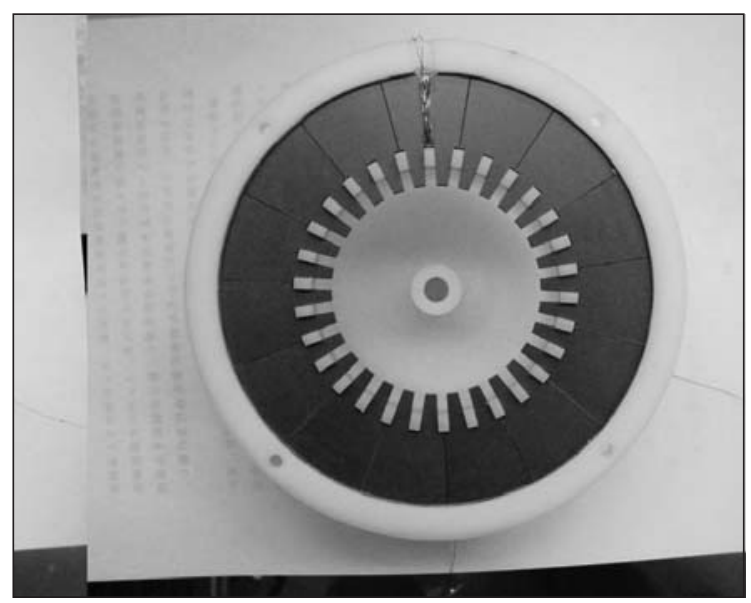

図 3 固定子用フレーム

Fig. 3. Stator frame.

Specimen

(Stator frame)

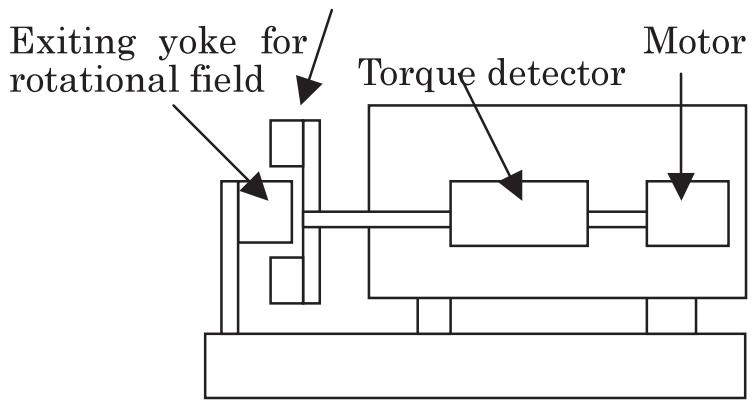

図 4 回転鉄損シミュレータ(7)

Fig. 4. Rotational core loss simulator ${ }^{(7)}$. 
ここで $W$ : 鉄損, $f:$ 分割コアへの励磁周波数, $T$ : トル ク, $M:$ 鉄心の重量である。

\section{3. 実験結果および考察}

〈3・1〉積層方法の影響回転鉄損シミュレータを用 いて固定子試料の鉄損を測定した。無方向性けい素鋼板 (50H350）の鉄損を図 5 に示す。鉄損は 30 から $60 \mathrm{~Hz}$ ま で測定し，これを基準として積層方法を変えた固定子の鉄 損と比較した。基準となる固定子鉄損は $50 \mathrm{~Hz}, 1.3 \mathrm{~T}$ にお いて $1.9 \mathrm{~W} / \mathrm{kg}$ である。

固定子試料に流れる磁束はギャップを通して分割された セグメントを渡るが，鋼板の積層方法によっても磁束の流 れが異なると考えられる。積層方法による面内渦電流分布 への影響は 3 次元解析で調べられているが(8) (11), 本研究で は鉄損の実測により，ヒステリシス損と渦電流損への鉄損 分離を行った。

変圧器の分野では数層おきに交互にギャップ位置を変え

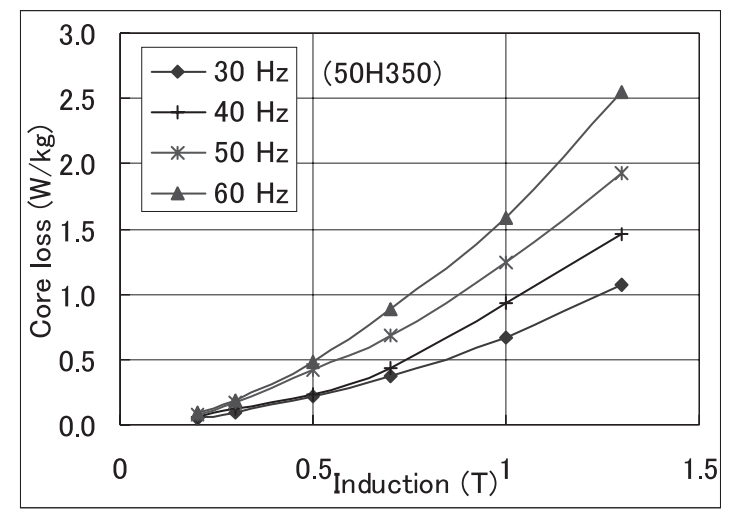

図 5 固定子鉄損 $(50 \mathrm{H} 350)$

Fig. 5. Core losses of stator $(50 \mathrm{H} 350)$.
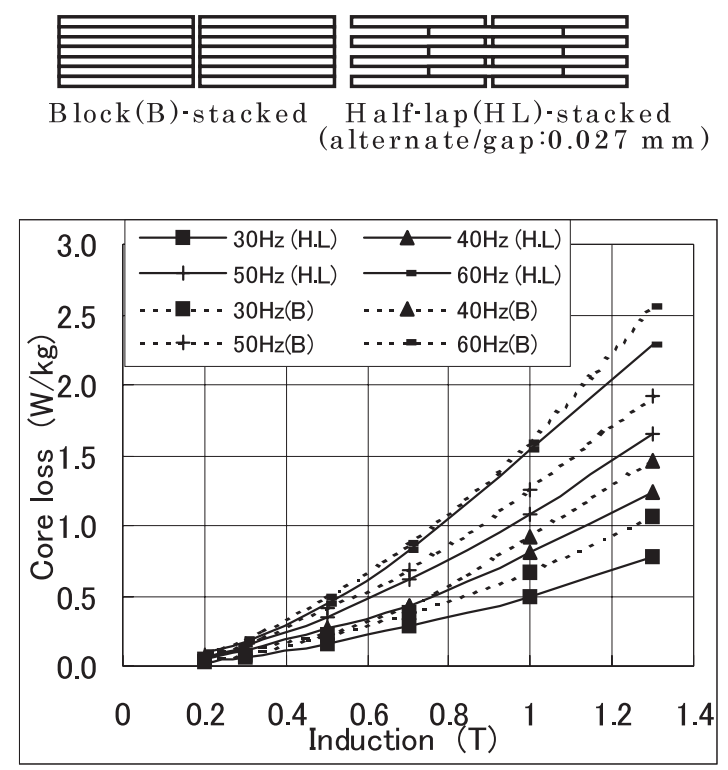

困 6 積層方法と鉄損 $(30-60 \mathrm{~Hz})$

Fig. 6. Stacking and core losses $(30-60 \mathrm{~Hz})$.
るマイター方式や, 階段状にギャップ位置を変えるステッ プラップ方式がある。本実験においてはこれらの積層方法 による鉄損の違いも定量的に調べた。

積層方法は同じギャップ位置でセグメントを積層するブ ロック積層（B）とギャップの位置を一層おきにセグメント の中心に配置するハーフラップ積層（H.L）を用いた。こ こでは B 積層と 1 層おきにギャップ位置がずれる H.L 積 層の鉄損を評価した。この鉄損を図 6 に示す。H.L 積層に することで 30-60 Hz の鉄損が約 10\%低下した。

図 7 では，これらの鉄損をヒステリシス損失と渦電流損 失に分離した。 $50,60 \mathrm{~Hz}, 1.3 \mathrm{~T}$ において B 積層は H.L 積 層より鉄損が高く，ヒステリシス損失の割合が大きかった。 これはギャップ間に発生する磁極が反磁界を形成するため, 透磁率が低下し, 励磁力が大きくなり, ヒステリシス損失 が増加したものと考えられる。

H.L 積層にすると鉄損が減少し，その中でもヒステリシ ス損失は大きく低下し, 一方で渦電流損失の割合は大きく なる。この理由は, H.L 積層においてギャップから漏れた 磁束が積層方向に渡り, 面内の渦電流が発生したためと考 えられる。

〈3・2〉 セグメント間のギャップの影響 〈3・1 節で記 した積層方法により，七グメント間ギャップの磁束流れの 変化が原因となり，鉄損に影響があると考えられる。ここ ではギャップ間隔を変えた場合の鉄損を評価する。

ギャップの影響は, 短冊状試料を用い実験と数值解析を組 み合わせ詳細に研究されている ${ }^{(12)}$ 。また, タービン発電機 セグメントにおけるギャップの影響が解析されているが (13), 本研究ではこの現象を 1/20 モデルにおいて実測した。

図 5, 図 6 の固定子のセグメントギャップは $0.027 \mathrm{~mm}(\mathrm{~B})$, 新たに測定する固定子のセグメントギャップは $0.8 \mathrm{~mm}(\mathrm{G})$ である。これらの固定子鉄損を図 8 に示す。

ギャップが大きい固定子は小さいものより鉄損が大きい。 特に周波数が大きい $60 \mathrm{~Hz}$, 磁束密度が高い $0.3 \mathrm{~T}$ の場合, その傾向が顕著である。これはギャップから漏洩した磁束

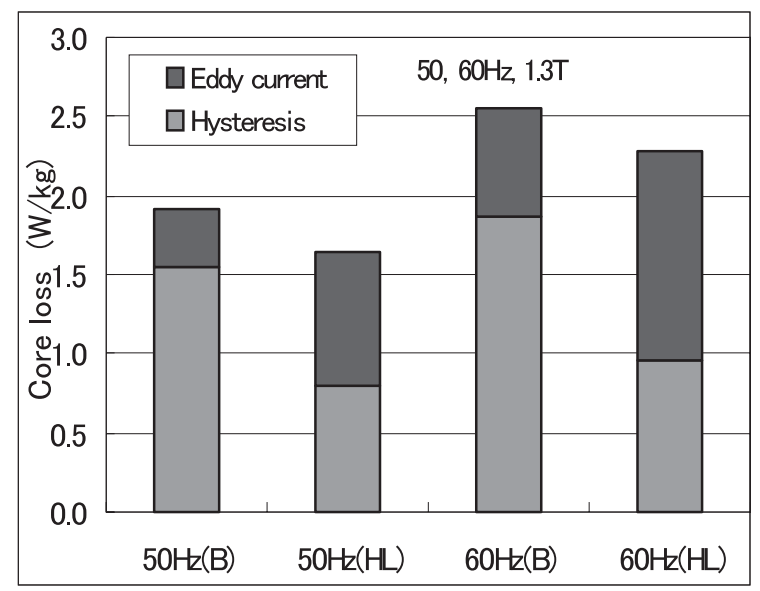

図 7 積層方法と鉄損分離 $(50 \mathrm{~Hz}, 1.3 \mathrm{~T})$

Fig. 7. Stacking and loss separation $(50 \mathrm{~Hz}, 1.3 \mathrm{~T})$. 
が隣接するセグメントに入る場合，ギャップ断面よりも面 内から入り，これによって面内渦電流損失が増加したため と考えられる。

また，ギャップが大きい固定子では規定の磁束密度にな るために大きな磁化力を必要とし, 測定できる磁束密度範 囲が狭い。

次にギャップ $0.8 \mathrm{~mm}$ で積層方法を変えた場合の鉄損を 図 9 に示す。ここで，H.L 積層は上 3 層と下 4 層を一つの ブロックとして，ギャップを配置したものである (3/4H.L)。 この配置は，七グメントギャップが広くなると，ギャップに はさむスペーサが鋼板板厚と同じ厚さになり，配置が難し くなるという技術的な理由から行った。H.L 積層と 3/4H.L 積層の磁束流れは等価ではないが，上下の積層鋼板に磁束 が渡る点では同じであり，以後， $0.8 \mathrm{~mm}$ ギャップで H.L 積 層の場合はこの条件で測定を行う。

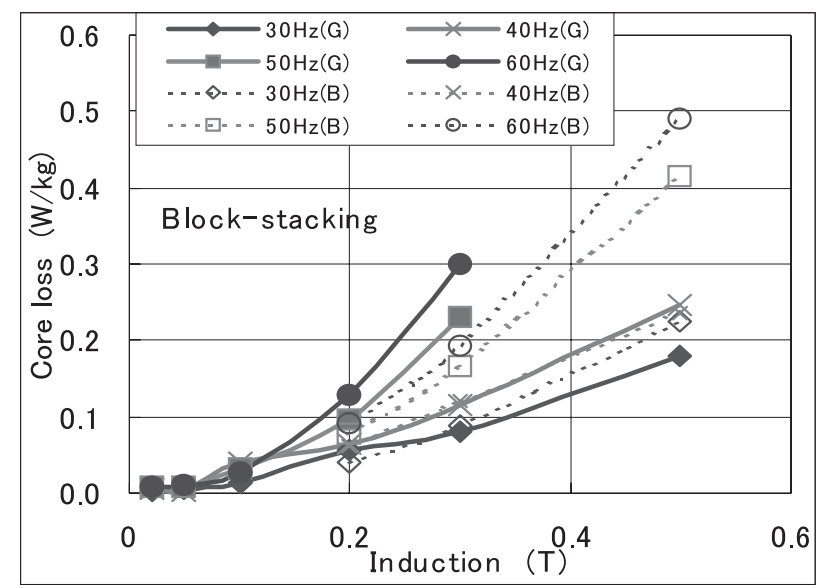

図 8 ギャップと鉄損 $(\mathrm{B}: 0.027 \mathrm{~mm}, \mathrm{G}: 0.8 \mathrm{~mm})$ Fig. 8. Segment gap and core losses (B: $0.027 \mathrm{~mm}, \mathrm{G}$ : $0.8 \mathrm{~mm})$.
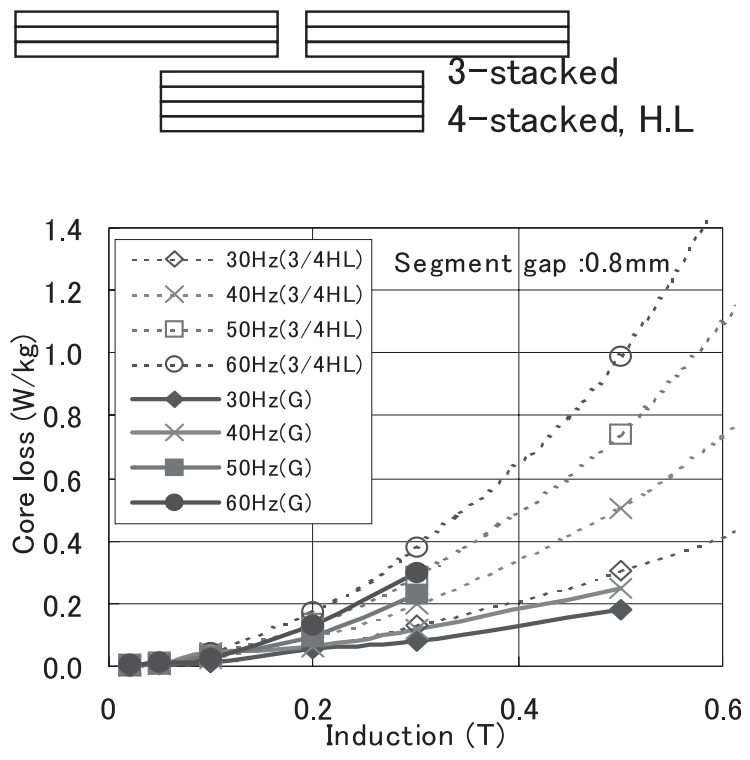

図 $90.8 \mathrm{~mm}$ ギャップ付きセグメントの積層方法と鉄損

Fig. 9. Core losses in $0.8 \mathrm{~mm}$-wide-gap segment core.
鉄損はく3・1 節とは逆に, 3/4H.L 積層にすると増加した。 〈3・1〉節ではギャップが狭いため磁束が隣のセグメントへ 渡り易かったが，ギャップが大きいと上下の積層鋼板に磁 束が渡るため, 面内渦電流損が発生し， G 積層より 3/4H.L 積層の鉄損が大きくなったと考えられる。

図 10 にヒステリシス損失，渦電流損失に分離した結果 を示す。 $50,60 \mathrm{~Hz}, 0.3 \mathrm{~T}$ においてギャップが大きいと渦 電流損失の割合が増加していることを確認した。周波数の 高い $60 \mathrm{~Hz}$ では渦電流損失の割合がさらに増加している。

図 11 はギャップが $0.8 \mathrm{~mm}$ で積層方法を変えた場合の鉄 損分離結果である。3/4H.L 積層では積層方向に磁束が渡り 易いためブロック積層より面内渦電流の割合が大きい。し たがって，渦電流損失の割合が大きいと考えられる。

$\langle\mathbf{3} \cdot \mathbf{3}\rangle$ 漏洩磁束の測定 今までの結果から, 鉄損の増 加は面内渦電流によるものと考えられる。ここで面内に入 る磁束を評価するために表面にサーチコイルを配置し，磁 束を測定した。サーチコイルは図 12 に示すように，セグ メントの中心とエッジに配置し, 磁束の分布を評価した。 サーチコイルは幅 $4 \mathrm{~mm}$, 長さ $22.5 \mathrm{~mm}$ で 10 回巻である。

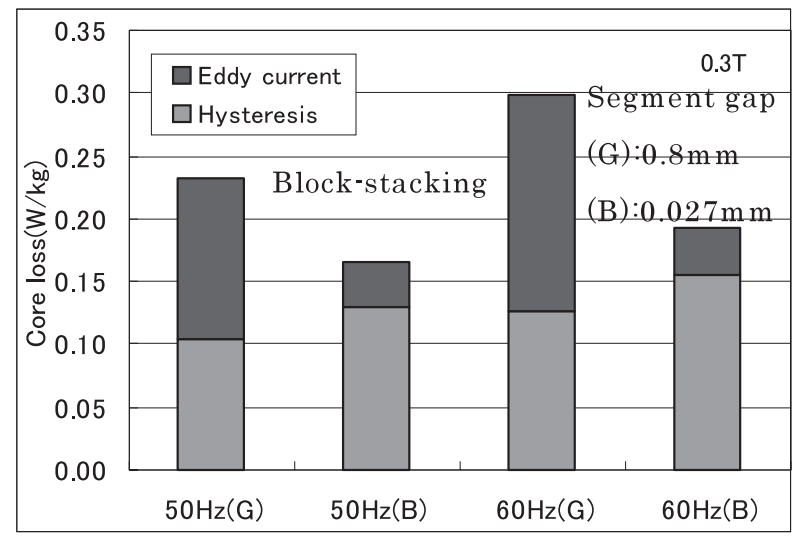

図 10 ギャップと鉄損分離 $(50,60 \mathrm{~Hz}, 0.3 \mathrm{~T})$

Fig. 10. Stacking and loss separation $(50,60 \mathrm{~Hz}, 0.3 \mathrm{~T})$.

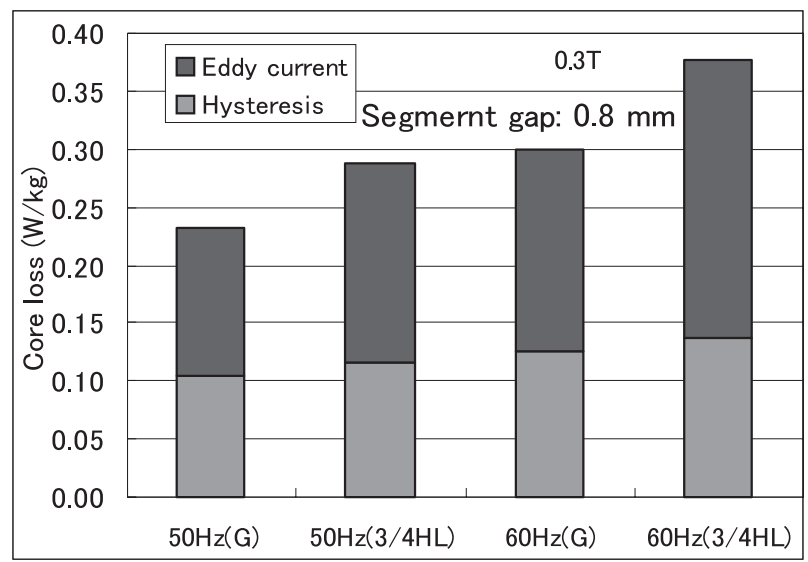

図 $110.8 \mathrm{~mm}$ ギャップ付きセグメントの積層方法と 鉄損 $(50,60 \mathrm{~Hz}, 0.3 \mathrm{~T})$

Fig. 11. Core losses in $0.8 \mathrm{~mm}$-wide-gap segment core $(50,60 \mathrm{~Hz}, 0.3 \mathrm{~T})$. 
右側は固定子断面の磁束密度を測定するコイルである。セ グメント間にはギャップを空けるため非磁性の紙をスペー サとして入れている。

測定結果を図 13 に示す。ギャップ無し $(0.027 \mathrm{~mm})$ で 積層数 7 枚の場合, 磁束密度は $0.005 \mathrm{~T}$ 以下である。中心 部とエッジ部で表面の漏れ磁束は少なく, 差は無い。一方, 図 14 のギャップあり $(0.8 \mathrm{~mm})$ の場合はエッジ部面内に入 る磁束密度は $0.02 \mathrm{~T}$ で，セグメント中心部面内に入る磁束 密度は $0.007 \mathrm{~T}$ であり, 明らかにギャップ近傍が高い。こ

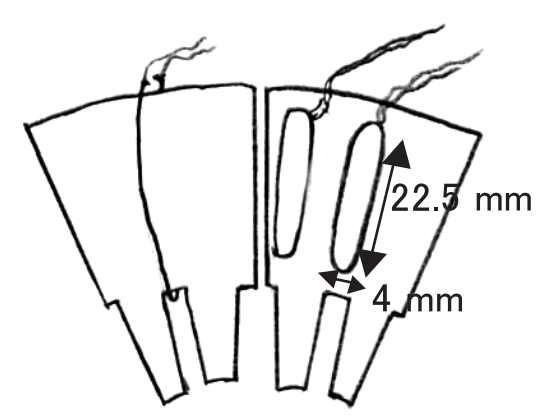

図 12 サーチコイルの位置

Fig. 12. Position of search coils.

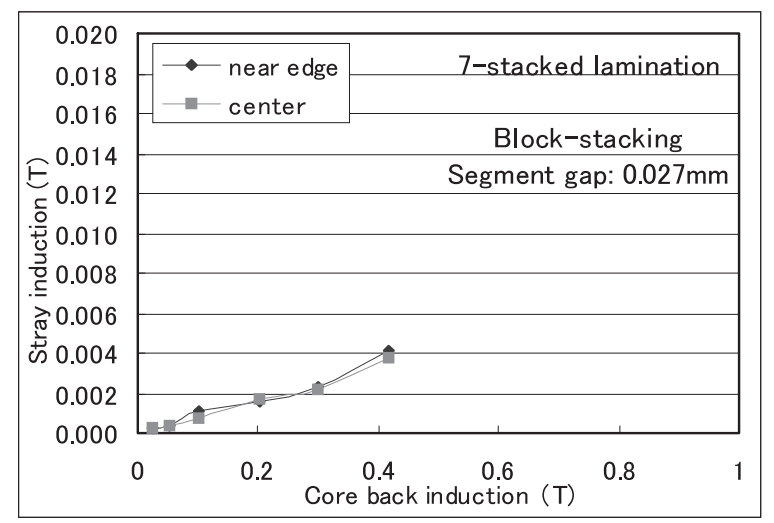

図 13 漏れ磁束の分布 (ギャップ $0.027 \mathrm{~mm}$ )

Fig. 13. Stray magnetic flux distribution (Segment gap: $0.027 \mathrm{~mm}$ ).

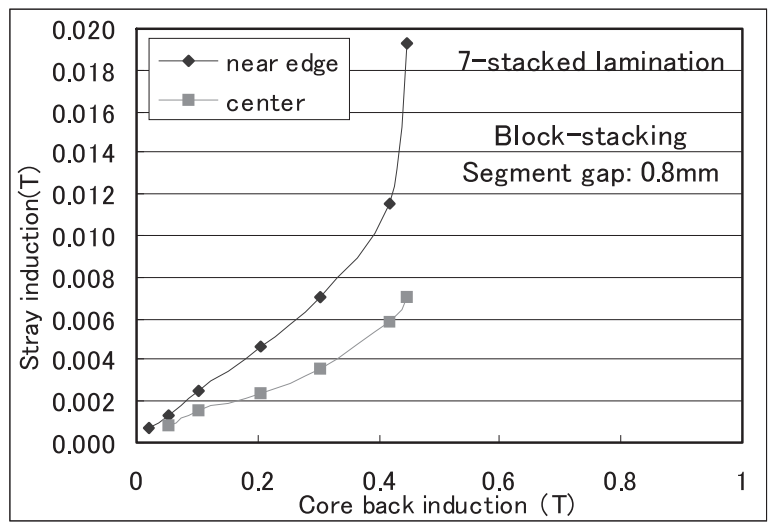

図 14 漏れ磁束の分布（ギャップ $0.8 \mathrm{~mm}$ )

Fig. 14. Stray magnetic flux distribution (Segment gap: $0.8 \mathrm{~mm})$.
の結果からギャップ近傍において，より多くの磁束がセグ メント面内に入ることを確認した。

図 15 はギャップ $0.8 \mathrm{~mm}$ のセグメントを $3 / 4 \mathrm{H} . \mathrm{L}$ 積層で 漏れ磁束を測定した結果である。この場合，ギャップが互 い違いに積層してあるため, 表面からの漏れ磁束が少ない。 これは重なり合う積層方向の鋼板に磁束が渡るためと考え られる。

〈3·4 ギャップモデルの解析 〈3·3 節では面内渦電

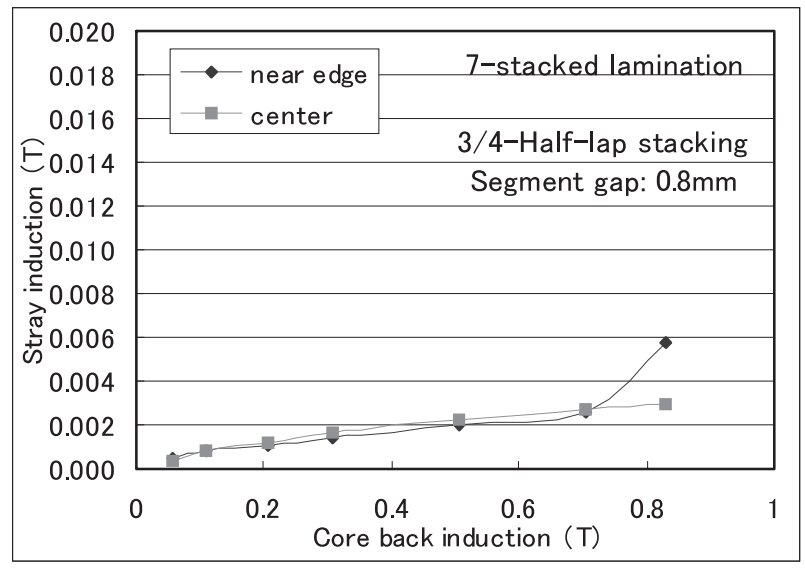

図 15 漏れ磁束の分布 (3/4 ハーフラップ. ギャップ $0.8 \mathrm{~mm})$

Fig. 15. Stray magnetic flux distribution (3/4-Half lap, Segment gap: $0.8 \mathrm{~mm}$ ).

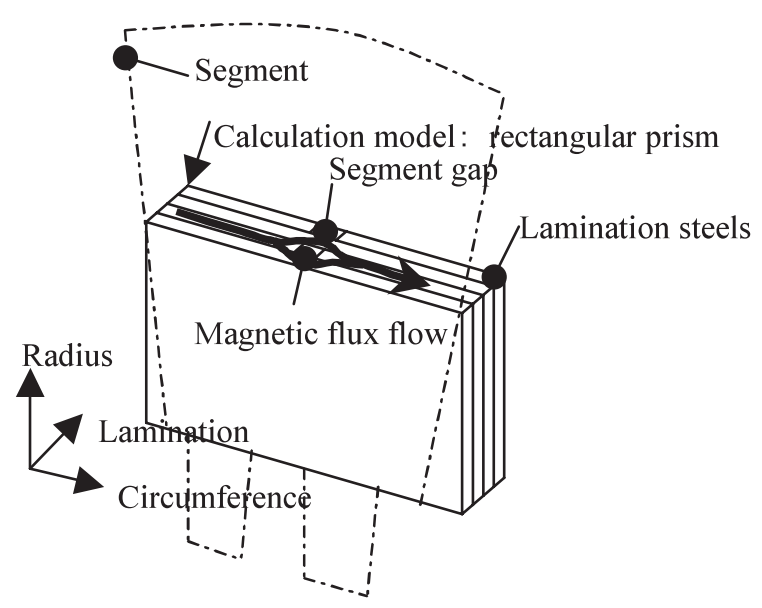

図 16 ギャップ領域モデル (14)

Fig. 16. Model of segment gap ${ }^{(14)}$.

表 1 ギャップモデルによる渦電流損失増加計算 (積層方法の影響)

Table 1. Calculation of eddy current loss increase on gap model. (influence of stacking).

\begin{tabular}{|c|c|c|}
\hline$\mu=12000$ (equivalent to 0.5 T) & $\begin{array}{c}\Delta \mathrm{W}(\%) \\
\text { Cal. }\end{array}$ & $\begin{array}{c}\Delta \mathrm{W}(\%) \\
\text { Meas. }\end{array}$ \\
\hline Without gap & 0 & 0 \\
\hline Half-lap 3 / 4 sheets $(0.8 \mathrm{~mm})$ & 250 & 218 \\
\hline Block-stacking (0.8 $\mathrm{mm})$ & 173 & $\cdots$ \\
\hline
\end{tabular}


流の影響の大きさを確認した。ここではタービン発電機の 付加的鉄損の要因解析として, 実験を元に図 16 のモデルを 用い，磁界解析により渦電流損失を計算した ${ }^{(14)}$ 。解析条件 は $50 \mathrm{~Hz}$ ，交流定常解析，線形計算（比透磁率 $\mu=12000$, $0.5 \mathrm{~T}$ 相当）で，励磁電流は一定とした。

表 1 に渦電流損失の増加割合 $\Delta \mathrm{W}$ の計算結果を示す。 3/4H.L において, 一定励磁条件下でギャップの影響により 渦電流損が $\mathrm{B}$ 積層より大きい実験事実を裏付ける結果が得 られた。

渦電流損失増加割合は実測 $218 \%$ に対し，計算結果は 250\%であった。これは実験条件が完全な「ギャップ無し」 を基準としていない $(0.027 \mathrm{~mm})$ ためで，これを考慮すれ ば実測と計算值の差は減少する方向である。

実測結果の割合は計算結果の割合の $87 \%$ をしており,

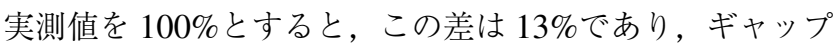
による渦電流損の影響は約 $13 \%$ 以内の誤差で推定できるこ とが検証された。

\section{4. まとめ}

タービン発電機モデルコアを作製し，鉄損を評価した。 今回の実験により以下の知見が得られた。

（1） ハーフラップ積層の方がブロック積層より約 $10 \%$ 鉄損が低く，渦電流損の割合が大きい。

（2）セグメント間のギャップが広いと渦電流損の割合 が大きく，面内渦電流損の影響と考えられる。

（3） ギャップモデルを用いた渦電流損失の影響は約 $13 \%$ 以内の誤差で推定できると考えられる。

今回の実験では，無方向性けい素鋼板（50H350）の鉄損 を大容量タービン発電機の $1 / 20$ モデルコアで評価し, 積層 方法やセグメントギャップの鉄損に対する影響を明らかに した。またギャップモデルによる計算結果と比較し，その 妥当性を検討した。

(平成 16 年 6 月 15 日受付, 平成 17 年 4 月 28 日再受付)

文献

(1) K. Hattori, K. Ide, K. Kobashi, I. Miyashita, H. Okabe, A. Semba, and T. Watanabe: "Development of a Highly Efficient Air-cooled Turbine Generator with Inner Coolers", The papers of Technical Meeting on Rotation Machinery, IEE Japan, RM-01-156, pp.157-161 (2001) (in Japanese) 服部憲一・井出一正・小橋啓司・宮下郁郎・岡部 宏 ·仙波章臣 · 渡辺 孝:「インナクーラ方式高効率空冷タービン発電機の開発」, 電 気学会回転機研資, RM-01-156, pp.157-161 (2001)

(2) K. Hattori, K. Ide, K. Kobashi, and T. Watanabe: "Air-cooled Large Turbine Generator with Inner Cooler Ventilation System”, CIGRE 2002, pp.11-104 (2002)

(3) K. Ide, K. Hattori, K. Takahashi, K. Kobashi, and T. Watanabe: "A Sophisticated Maximum Capacity Analysis for Large Turbine Generators Considering Limitation of Temperature", IEMDC 2003, Madison, Wisconsin, U.S.A., (2003-6)

(4) S.A. Holland, J.W. Pratt, and P.J. Tavner: "Increasing the Power-weight Ratio of Modern Air-cooled Turbogenerators? Opportunities \& Pitfalls", the $15^{\text {th }}$ MMRG Seminar, Manchester, $1^{\text {st }}(2002-11)$

(5) G. Klaus, M. Liese, K. Takahashi, K. Ide, K. Hattori, and T. Watanabe: "Development of a Calculation Program for Evaluation of the Stator Core End Design of Air Cooled Turbine Generators", The papers of Technical Meeting on Rotation Machinery, IEE Japan, RM-02-128, pp.121-126 (2002)

(6) G. Klaus, M. Liese, K. Takahashi, K. Ide, K. Hattori, and T. Watanabe: "Calculation of Losses and Temperature Rises at the Stator Core Ends of Air Cooled Turbine Generators Considering the Stator Slot End Field", The papers of Technical Meeting on Rotation Machinery, IEE Japan, RM-03113, pp.1-6 (2003)

( 7 ) C. Kaido: "Mechanical Method of Iron Loss Measurement in a Rotational Field and Analysis of Iron Loss in a Motor", J. Appl. Phys., Vol.69, No.8, pp.5106-5108 (1991)

(8) A.G. Jack and B.C. Mecrow: "The calculation of three dimentional electromagnetic fields involving laminar eddy currents", IEE Proc. A (1987-9)

(9) T.W. Preston and M.A. Timothy: "Eddy current distribution in segmented stator core laminations", Univ. Power Engng. Conf., pp.631-634 (1990)

(10) S. Wakui, K. Takahashi, K. Ide, M. Takahashi, and Y. Yagi: "3D Magnetic Field Analysis of 70 MVA Class Turbine Generator", The papers of Technical Meeting on Rotation Machinery, IEE Japan, RM-98-115 (1998) (in Japanese)

湧井真一・高橋和彦・井出一正・八木恭臣：「70 MVA 級夕ービン発 電機の 3 次元磁界解析」, 電気学会回転機研資, RM-98-115 (2001)

(11) P.J. Tavner: "Cross-magnetisation effects in electrical machines", IEE Proc.Electr. Power Appl., Vol.151, No.3, pp.249-259 (2004-5)

12) T. Nakata and Y. Kawase: "Analysis of Magnetic Properties at lamination Joints", IEE Japan, Vol.102, No.2, 57-B8, pp.1-8 (1982-2) (in Japanese) 中田高義 ·河瀬順洋 : 「積層鉄心接合部の磁気特性の解析」,電学論, 102, 2, pp.1-8 (1982-2)

(13) T.GW. Phemister and C. Wymer: "The effects of gaps between laminations on axial flux and eddy currents in an idealized stator core", COMPUMAG, section 3.6 (1978)

(14) A. Nakahara, H. Mogi, K. Takahashi, K. Ide, J. Kaneda, K. Hattori, T. Watanabe, C. Kaido, E. Minematsu, and K. Hanzawa: "Analysis of No-load Iron Losses of Turbine Generators by 3D Magnetic Field Analysis", IEEJ Trans. IA, Vol.124, No.8, pp.830-836 (2004-8) (in Japanese)

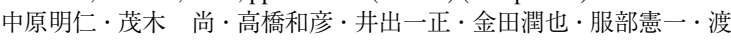
辺 孝 ·開道 力・峰松英資 - 半澤和文：「三次元磁界解析を用いた タービン発電機の無負荷時鉄損の分析」, 電学論 D, 124, 8, pp.830-836 (2004-8)

茂木

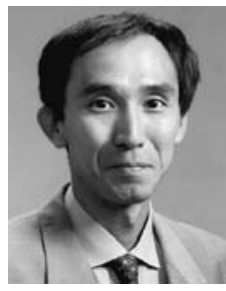

中 原 明 仁

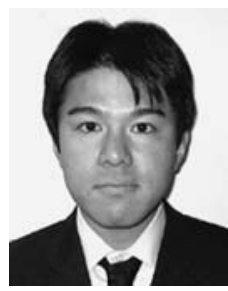

高 橋 和 彦

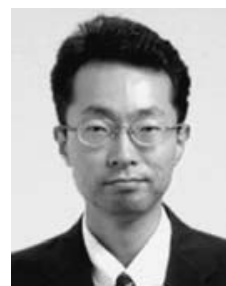

尚（正員） 1966 年 3 月 6 日生。1990 年 3 月東北大 学大学院工学研究科電子工学専攻博士前期課程修 了。同年 4 月新日本製鐵（株）入社。主として, 電磁鋼板の製造技術，磁気物性及び磁気応用等の 研究に従事。現在，同社技術開発本部鉄鋼研究所 鋼材第一研究部主任研究員。工学博士。1996 年 日本鉄鋼協会澤村論文賞受賞。IEEE 会員。 


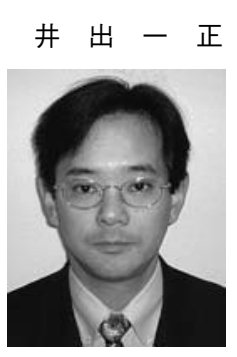

（上級会員） 1964 年 1 月 5 日生。 1988 年 3 月東 北大学大学院工学研究科電気及通信工学専攻博士 前期課程修了。同年 4 月（株）日立製作所入社。 現在, 研究開発本部日立研究所主任研究員。発電 機をはじめとする回転機の研究開発に従事。工学 博士。1 1992 年, 1994 年電気学会論文発表賞, 1993 年 2001 年電気学会論文賞, 1999 年日本電機工業 会奨励賞, 2003 年オーム技術賞各受賞。日本応用

磁気学会, IEEE 会員。

開 道 力 (正員) 1950 年 9 月 7 日生。1975 年 3 月東京工

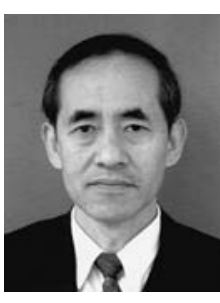
業大学大学院工学研究科電子物理工学専攻修士課 程修了。同年新日本製鐵 (株) 入社。主として, 電 磁鋼板をはじめとする磁性材料の磁気物性, 磁気 応用，及び計測等の研究に従事。現在，同社技術 開発本部鉄鋼研究所鋼材第一研究部主幹研究員。 九州工業大学客員教授兼務。工学博士。2003 年 日本鉄鋼協会白石記念賞受賞。

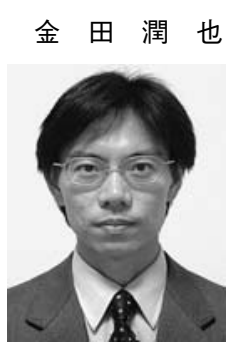

(非会員) 1967 年 9 月 7 日生。1992 年 3 月九 州大学工学研究科応用原子核工学専攻修士課程修 了。同年 4 月（株）日立製作所入社。日立研究所 に勤務し，金属材料の研究開発に従事。

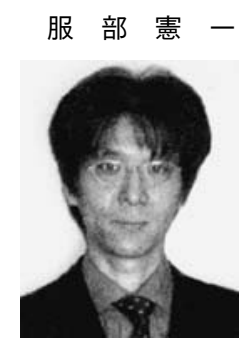

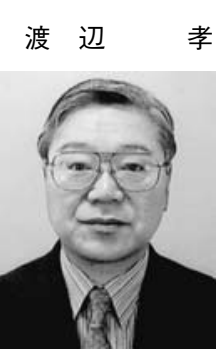

孝 (非会員) 1944 年 2 月 14 日生。(株) 日立製作 所入社。主として, タービン発電機の設計・開発 に従事。現在, 電力・電機グループ電機システム 事業部主管技師。工学博士。日本機械学会会員。

峰 松 英 資 (非会員) 1957 年 7 月 15 日生。1982 年 3 月慶

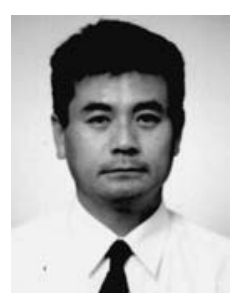
応義塾大学大学院機械工学科卒。同年 4 月新日本 製鐵（株）入社。八幡製鐵所電磁鋼板部, 欧州事 務所, 本社薄板事業部電磁鋼板営業部, 名古屋支 店に勤務し, 主に電磁鋼板の品質管理, 開発業務 に従事。

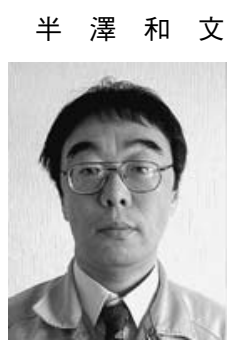

(非会員) 1957 年 12 月 4 日生。1982 年 3 月東北 大学理学部化学科卒業。同年 4 月新日本製鐵（株） 入社。八幡製鐵所製鋼部，東南アジア事務所，八 幡製鐵所電磁鋼板工場に勤務し, 主に電磁鋼板の 品質管理, 開発, 技術サービス業務に従事。 